\title{
The consumer perspective: A consultation with senior health officials from developing countries on standards of evidence for reproductive and maternal health care
}

The Evidence Project

STEP UP Research Programme Consortium

Follow this and additional works at: https://knowledgecommons.popcouncil.org/departments_sbsr-rh

Part of the Demography, Population, and Ecology Commons, Family, Life Course, and Society Commons, Health Policy Commons, International Public Health Commons, Maternal and Child Health Commons, and the Women's Health Commons How does access to this work benefit you? Let us know!

\section{Recommended Citation}

Evidence Project and STEP UP. 2016. "The consumer perspective: A consultation with senior health officials from developing countries on standards of evidence for reproductive and maternal health care," STEP UP Meeting Report. Washington, DC: The Evidence Project and STEP UP. 
USAID Evidence

\section{$\mathbf{N}$ Vas UKaid \\ STEP SUP}

\section{The Consumer Perspective:}

A Consultation with Senior Health

Officials from Developing Countries on

Standards of Evidence for Reproductive and Maternal Health Care

APRIL 2016

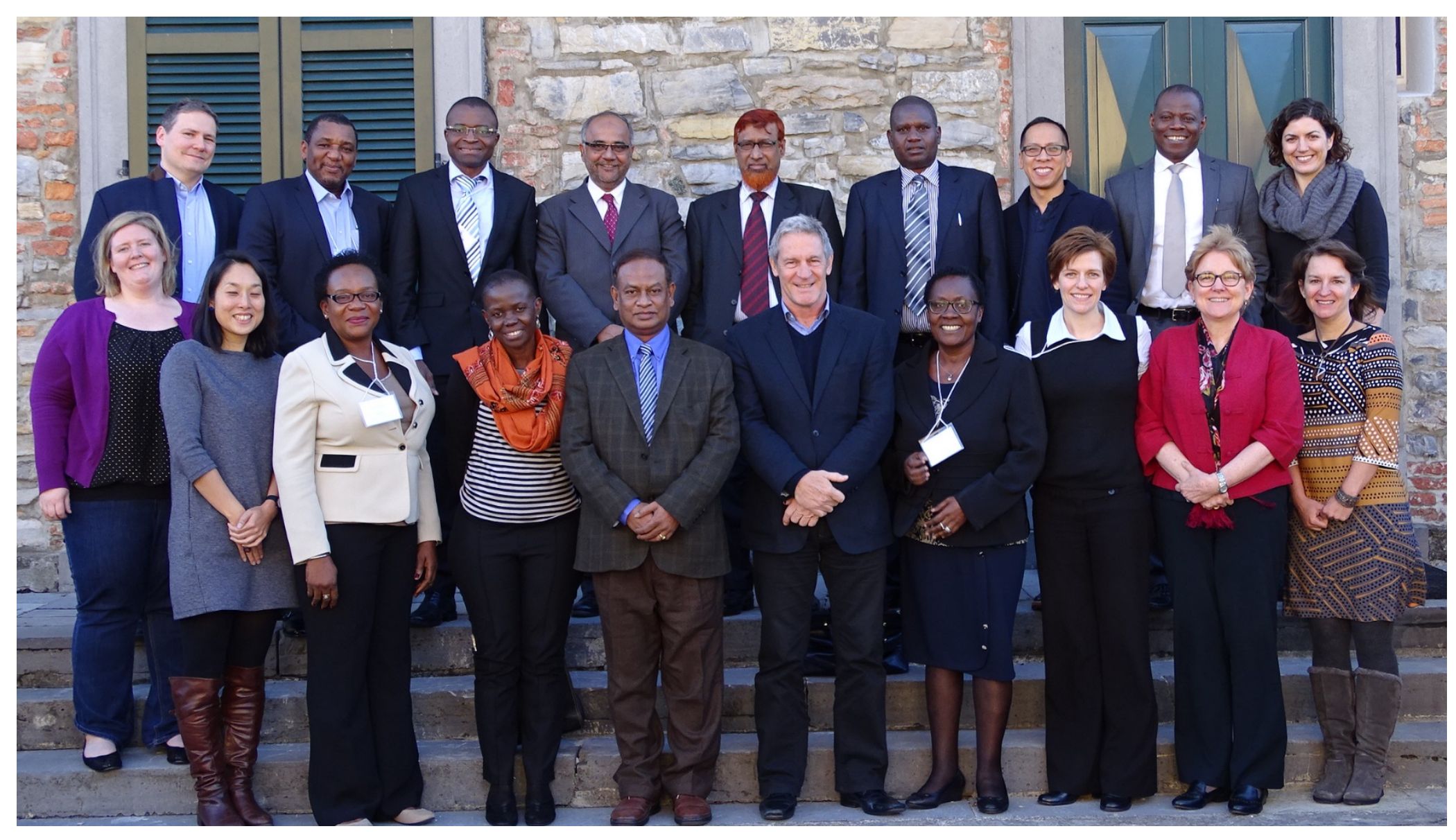




\section{The Evidence Project}

Population Council

4301 Connecticut Avenue, NW, Suite 280

Washington, DC 20008 USA

tel +12022379400

evidenceproject.popcouncil.org

The Evidence Project is made possible by the generous support of the American people through the United States Agency for International Development (USAID) under the terms of cooperative agreement no. AID-OAA-A-13-00087. The contents of this document are the sole responsibility of the Evidence Project and Population Council and do not necessarily reflect the views of USAID or the United States Government.

\section{Evidence}

The Evidence Project uses implementation science-the strategic generation, translation, and use of evidence - to strengthen and scale up family planning and reproductive health programs to reduce unintended pregnancies worldwide. The

Evidence Project is led by the Population Council in partnership with INDEPTH Network, International Planned Parenthood Federation, PATH, Population Reference Bureau, and a University Research Network.

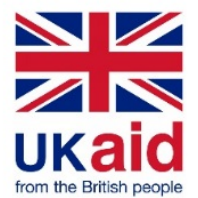

The STEP UP project is made possible by the generous funding of UK aid from the UK government and the British people; however the views expressed do not necessarily reflect the UK government's official policies.

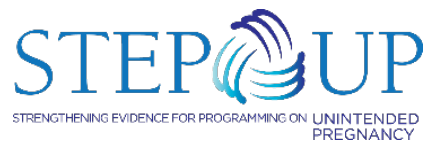

The STEP UP (Strengthening Evidence for Programming on Unintended Pregnancy) Research Programme Consortium generates policy-relevant research to promote an evidence-based approach for improving access to family planning and safe abortion. STEP UP focuses its activities in five countries:

Bangladesh, Ghana, India, Kenya, and Senegal. STEP UP is coordinated by the Population Council in partnership with the African Population and Health Research Center; The International Center for Diarrhoeal Disease Research -Bangladesh (icddr-b), the London School of Hygiene and Tropical Medicine; Marie Stopes International; and Partners in Population and Development. STEP UP is funded by UK aid from the UK Government. www.stepup.popcouncil.org

Published in 2016.

Suggested citation: The Evidence Project and STEP UP. 2016. "The Consumer Perspective: A Consultation with Senior Health Officials from Developing Countries on Standards of Evidence for Reproductive and Maternal Health Care," Meeting Report. Washington, DC: Population Council, The Evidence Project and STEP UP.

Photo credit on cover page: (C2016 The Rockefeller Foundation

(C) 2016 The Population Council, Inc. 


\section{Table of Contents}

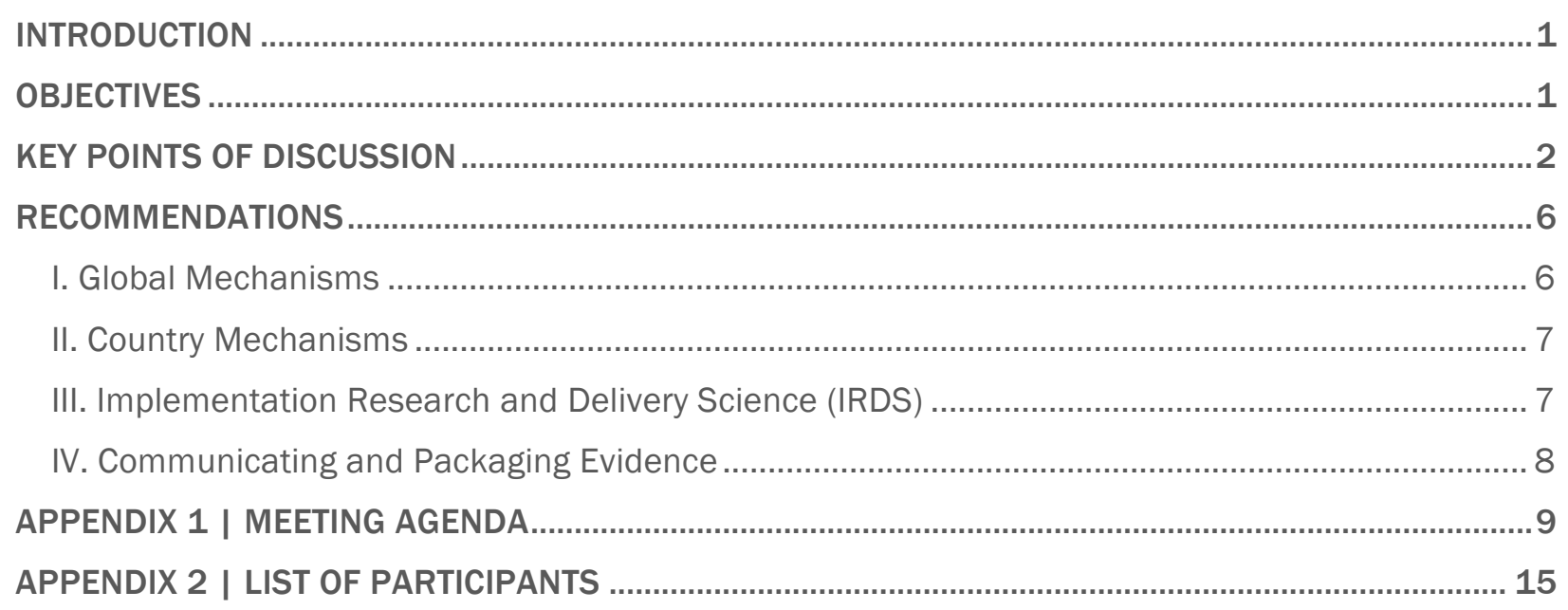




\section{Introduction}

The Population Council (through the STEP UP consortium and the Evidence Project) and the High Impact Practices (HIP) Collaboration, together with other partners, held a series of three consultative meetings around the topic of standards of evidence in reproductive and maternal health. The first consultation was held in New York (18-19 June 2013) and focused on the generation and synthesis of evidence to inform the production of HIP briefs. The second consultation was held in Croydon, UK (18-19 September 2013) and brought together researchers and funders of research to discuss and develop recommendations to improve research design and methodologies to generate evidence on the implementation and impact of $\mathrm{FP} / \mathrm{RH}$ interventions; review mechanisms and structures for this evidence; and maximize quality and utility of evidence generation.

The third and final meeting in the series was held in Bellagio, Italy from 9-11 February 2016. The meeting brought together developing country decision-makers (see Annex B for participant list) to vet, from the research "consumer" perspective, the recommendations that emerged from the second consultation and to elicit further recommendations on how to better generate and package evidence to meet the needs of decision-makers. Also in attendance were donors, multi-lateral organizations, and researchers from the second consultation, so that they could better understand the decision-makers' perspectives and to forge connections between "producers" and "consumers" of evidence.

\section{Objectives}

Nineteen developing country decision-makers, representatives of donors and multi-lateral organizations, and researchers participated in the two-and-a-half day meeting. The meeting was structured in a participatory format, with a moderator initiating and facilitating discussion among participants. Most session moderators were country decision-makers.

The goals of the Bellagio meeting were to:

- Share with national decision-makers the recommendations for standards of evidence developed during the two previous consultations, including types of studies, to determine their applicability in developing country contexts;

- Understand with greater insight how research evidence, along with other types of evidence, is currently used by national decision-makers and the factors facilitating or inhibiting use of evidencebased best practice recommendations;

- Reach agreement on how research can be designed and implemented to best help national decisionmakers achieve their goals;

- Reach agreement on how research results can be synthesized, packaged, and communicated most appropriately for informing the various types of decisions made by national and sub-national health system stakeholders. 


\section{Key Points of Discussion}

On the first morning, to help frame the discussion, Dr. Ian Askew from the World Health Organization (WHO) provided a brief overview of the second consultation at Croyden and the relevant recommendations that emerged from that meeting (see Annex A for full agenda).

Following this synopsis, Dr. Patrick Aboagye from the Ghana Health Service led a country decision-maker discussion on the topic of "policy and programs from the decision-maker perspective," and the role for research-based evidence, with the intent of eliciting the decision-makers' real life experiences and challenges around evidence use. An Evidence Project working paper titled "Family Planning Policy, Program, and

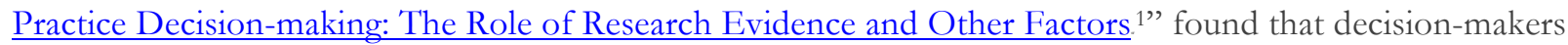
often have a broader definition of "evidence" than researchers, that evidence tends to be just one of many factors in decision-making, and that evidence use is a non-linear process, with use occurring at various points in the decision-making process. Discussion among participants reinforced all of these points, particularly that evidence use is not always a uniform part of decision-making, but rather can occur at various stages and for various purposes in the decision-making process. For example, some decisions have to be made very quickly and there is not time for rigorous research designs to answer the question - decision-makers need to reach out to the most convenient, readily available source for evidence. In other instances, evidence is sought to justify continued investment in a decision that has already been made. These examples highlight the complexity and challenges of evidence-based decision-making.

Key issues were raised around the themes of what types of evidence consumers want, as well as the time it takes to generate this evidence through research. Decision-makers made the point that they are often not looking for evidence from randomized controlled trials or systematic reviews, but operational evidence that can inform program investments and their implementation. A challenge for decision-makers as research consumers is the time required to conduct primary research that may be necessary to generate the information needed for them to use to improve programming.

Decision-makers also raised the issue that politicians often look to them for very quick, evidence-informed answers to questions so that they can rapidly respond to issues arising in parliament or among their constituents. This presents a challenge, as undertaking research is not an option in these situations, given time constraints. Decision-makers need options to access rigorous evidence quickly to be able to respond to these requests. The group discussed existing examples of rapid response mechanisms, although the definition of "rapid" varies and it is not clear how sustainable these mechanisms are without donor funding.

Another issue raised in this session is communication between researchers and decision-makers on how research agendas are identified, as well as on whether the results produced from research are relevant for decision-makers. It is important to balance research agendas of external donors who fund the studies to achieve their goals with those of country decision-makers who need the evidence to improve their programs. Research prioritization should start with dialogue between donors, researchers and policy makers so that those expected to use the evidence are aware of and understand the research being done - in the absence of dialogue and understanding, decision-makers can become barriers to conducting and using research, rather than champions. Dialogue would also help to align the research with country needs, thereby gaining buy-in from key end users. The discussion also highlighted many common challenges of ensuring that the research consumers have knowledge of and access to the results once the research is completed; for example, all

${ }^{1}$ http://evidenceproject.popcouncil.org/wp-content/uploads/2015/09/Role-of-Evidence-Working-Paper.pdf 
participants emphasized the importance of open access to journal publications to remove cost barriers to country end users.

Decision-makers emphasized that the government needs to be closely connected to research from the beginning, so that scale up of the results is accepted as the responsibility of the government and not just a recommendation given to them at a dissemination meeting, with no plan for implementation. Sometimes decision-makers aren't even aware of relevant research that was done in their country and only learn of it at a conference or similar venue, which shows a potential disconnect between producers and consumers of research.

Following this discussion, key issues related to standards of evidence were discussed, with presentations by Karen Hardee of the Population Council and Director of the Evidence Project, Nhan Tran from the WHO, and Özge Tunçalp from the WHO.

Dr. Hardee gave a presentation on "Standards and Types of Evidence for Clinical, Public Health, and Multisectoral Interventions." She discussed the importance of using different study designs depending on the evidence needed, as they can answer different types of questions and add greater nuance to the evidence. For example, as shown in Figure 1, qualitative evidence is useful for assessing service delivery processes, acceptability, appropriateness, and service satisfaction, as it gets to people's perceptions and adds important context to the quantitative data.

FIGURE 1 | EXAMPLE OF A TYPOLOGY OF EVIDENCE FOR SOCIAL INTERVENTIONS FOR CHILDREN

\begin{tabular}{|c|c|c|c|c|c|c|c|}
\hline Research question & $\begin{array}{l}\text { Qualitative } \\
\text { research }\end{array}$ & Surveys & $\begin{array}{c}\text { Non- } \\
\text { experimental } \\
\text { evaluations }\end{array}$ & $\begin{array}{l}\text { Case- } \\
\text { controlled } \\
\text { studies }\end{array}$ & $\begin{array}{l}\text { Cohort } \\
\text { studies }\end{array}$ & $\begin{array}{l}\text { Randomized } \\
\text { control trials }\end{array}$ & $\begin{array}{c}\text { Systematic } \\
\text { reviews }\end{array}$ \\
\hline Effectiveness & & & & & + & ++ & +++ \\
\hline $\begin{array}{l}\text { Process of service } \\
\text { delivery }\end{array}$ & ++ & + & + & & & & +++ \\
\hline Salience & ++ & ++ & & & & & +++ \\
\hline Safety & + & & + & + & + & ++ & +++ \\
\hline Acceptability & ++ & + & + & & & + & +++ \\
\hline Cost effective & & & & & & ++ & +++ \\
\hline Appropriateness & ++ & ++ & & & & & ++ \\
\hline $\begin{array}{l}\text { Satisfaction with } \\
\text { services }\end{array}$ & ++ & ++ & & + & + & & + \\
\hline
\end{tabular}

Dr. Hardee also stressed that researchers should be flexible in designing their studies in order to meet the needs of the end user (while retaining its rigor and high quality) and that the results should be implementable by national programs. Finally, she discussed what is known about how decision-makers use research evidence in the decision-making process, including how it is supplemented with other types of evidence, such as personal or professional experience and anecdotal evidence, and how research evidence is perceived through an individual's beliefs and values, as well as external constraints, before a decision is made. 
Dr. Tran then presented on using implementation research to inform scale up and improve program efficiency. He discussed the need for research to be more dynamic and iterative, rather than producing linear outputs, outcomes, and impact, since policy making and implementation is not always a rational, linear process. Echoing Dr. Hardee, he noted that it is incorrect to assume that there is a single solution to complex challenges, i.e. that one research design can answer multiple questions. Dr. Tran also made the point that implementation of research findings often has to be done with limited information. A report entitled "Enabling efficient policy implementation". 2 found that poor implementation is widespread, with common reasons including poor planning, the complexity of consistent implementation, and push-back or lack of interest from health professionals responsible for implementation. Finally, research needs to take the social and political context and health systems into consideration, and take advantage of unexpected opportunities that may present themselves.

Dr. Tunçalp closed the session by presenting on "From Evidence to Guidelines: what's in an acronym?” She summarized the WHO guideline development process and the effort to make the guidelines more focused on questions not just of effectiveness, but also acceptability and feasibility, which are issues important to decision-makers. This was done through the development of the DECIDE (Developing and Evaluating Communication Strategies to Support Informed Decisions and Practice Based on Evidence) framework (which is complementary to the GRADE (Grading of Recommendations Assessment, Development and Evaluation) framework). In the WHO guideline development process, questions of efficacy and safety are answered with systematic reviews of controlled studies, while acceptability and feasibility are answered with systematic reviews of qualitative research. To answer the question of how decision-makers, who are often not themselves research experts, can be confident in the quality of evidence, particularly qualitative evidence, Dr. Tuncalp reviewed the GRADE CERQual (Confidence in the Evidence from Reviews of Qualitative research) process. Finally, the presentation closed with an overview of the ongoing process to help make global level guidelines more useful and easier to adapt and implement at the country level.

Day one closed with a discussion of the role of politics and opinion in assessing standards of evidence, facilitated by Dr. Josephine Kibaru from the National Council for Population and Development in Kenya. The discussion covered a variety of challenges, including the need for consensus building and to engage a variety of politicians at different levels, not just the federal level. Increased decentralization makes this especially important: even if research results in a policy change at the federal level, implementation of the new policy could be hindered if sub-national level politicians and decision-makers were not involved, particularly if the change required is substantial. There can also be political challenges to bringing in evidence and experiences from other countries, as there can be sensitivity around which countries are used for comparison. Conversely, countries will often find global evidence insufficient and will want research on how a policy or intervention would work locally before implementation.

A number of issues were cited related to the influence of political factors on evidence use in decision-making. This included frequent turnover of politicians at the highest levels of decision-making, though it was noted that engaging civil servants, who tend to stay in their positions for longer periods, can mitigate that. Political hierarchy can also hinder the use of research evidence in policy making since, for example, it can be difficult to ensure that research evidence is communicated effectively through the hierarchy to reach the highest levels of decision-making. Professional associations and nongovernmental organizations were mentioned as stakeholders that should be engaged to help overcome these challenges, as they can be very influential in the policy process. Another method to overcome political challenges is the identification of effective champions who can help to ensure that evidence and accurate information reaches politicians.

${ }^{2}$ http://www.oracle.com/us/industries/public-sector/economist-report-193495.pdf 
Day two opened with a discussion among country decision-makers, facilitated by Susan Elden from DfID, of their perspectives on country-level research agendas, research coordination, and challenges to evidence generation or access to evidence at the country level. It was agreed that decision-makers generally do not have the ability or time to determine the quality of research evidence on their own; discussion focused on if and how in-country arbiters of good and poor research methodology could help decision-makers assess the quality of evidence from national and international sources. Potential arbiters of research evidence included universities, professional associations, or technical working groups that have credibility. In Bangladesh, for example, professional associations are engaged in research review. Generally, it was agreed that there is not a one-size-fits-all solution and that each country needs to determine for themselves what entities could play this role. There was agreement, however, that decision-makers do need a mechanism to help them judge the quality of research, since the quality will impact the results. Discussion concluded with a conversation about whether more global guidance is needed to help country decision-makers assess the quality of evidence, similar to guidance ${ }^{3}$ that DfID has produced.

Dr. Koku Awoonor-Williams from the Ghana Health Service facilitated a discussion among the researchers, multi-lateral representatives, and donors to discuss their perspectives on these topics, including if and how research needs to better align with country research agendas and how research can be better coordinated among all partners. This discussion also addressed the importance of donors having more of a culture of embedding research and learning into program implementation and a more diverse portfolio of research mechanisms (seed grants, grand challenges, implementation research, clinical trials, and so forth) to enable more country-level opportunities for different stakeholders to be involved in the research process.

Discussion for the remainder of the second day covered packaging and communication of evidence. Three means of communicating evidence were reviewed and discussed (a single journal article, High Impact Practice briefs, and WHO global guidance) to gain decision-maker perspectives on the usefulness of these documents in their current form and what could be done to make them more understandable and accessible to encourage use. The discussion also focused on what types of evidence the decision-makers preferred, what they would like more of, and what they felt were the most effective methods of communicating evidence to decisionmakers. The importance of open access journals was reiterated, as the requirement to pay or have a subscription to access an article can be a hindrance for decision-makers to access evidence.

Other important suggestions made by the decision-makers for how better to communicate evidence include:

- Presentations on research evidence to targeted sub-groups

- Use of concise summaries and plain language in communication of evidence

- Sending research reports (or briefs with key information from the report) to ministries

- Recognizing the varied information needs of different audiences and the importance of "marketing" evidence to different audiences, not just disseminating it

- Global-level web repositories or packaging of information to encourage access and collaboration

- Having research "teams" comprising those working on both the research and the use/communication of that research, and ensuring appropriate timing of engagement of all parties

- Using various means of communicating evidence including briefs, video, e-mail digests, etc.

It was agreed that public health is the intersection of both politics and science, which reflects the idea that decision-makers and researchers should be working as partners to ensure that needed questions are being generated, that research asks these questions in the right way, and that the evidence generated will be used to translate research into practice.

\footnotetext{
${ }^{3}$ https://www.gov.uk/government/uploads/system/uploads/attachment_data/file/291982/HTN-strength-evidencemarch2014.pdf
} 


\section{Recommendations}

The recommendations that emerged from the Bellagio consultation fall into four major categories: Global mechanisms, country mechanisms, implementation research and decision science (IRDS), and packaging and communication of evidence.

\section{GLOBAL MECHANISMS}

Among sources of evidence, the discussion highlighted that WHO global guidance is one of the most trusted, particularly when other sources of evidence are scarce. Country decision-makers recognize that national health systems see the value of and benefit from global guidance, particularly guidance developed by the WHO. However, it was also acknowledged that global guidance can't answer every question, particularly when it comes to local context.

a. The relevance and applicability of WHO guidance could be further strengthened by applying new methodologies for synthesizing and appraising a broader range of evidence, such as evidence from qualitative studies and complex interventions.

The meeting participants also underscored a conclusion from the Croydon meeting that "different decisions require different types of evidence generated through different study designs; consequently the utility of research-based evidence will depend on its capacity to inform a particular decision." The flexibility of having multiple study design options may better allow for non-traditional sources of evidence, such as grey literature, expert opinion, and implementation experience to be taken into account. This broad range of sources allows for a nuanced interpretation of evidence that can address a wider range of questions, such as: Who directly benefits from program investments? In what context? This also allows for the incorporation of additional dimensions such as scale and cost of intervention implementation. Taken together, WHO guidance and complementary sources of evidence may provide a more comprehensive interpretation for policy makers.

b. We recognize that policy makers and program managers have a range of information needs that cannot be addressed with WHO guidance alone. Therefore, we stress the need for continued investment in complementary processes, resources, and capabilities at all levels for generating, synthesizing and communicating evidence.

Inconsistent knowledge about and messaging of new research findings at the global and country levels can hamper evidence-based programming at the country level.

c. Development partners including UN organizations must ensure alignment and consistency of messaging for research findings and results at the regional and country levels.

At the country level, decision-makers are often faced with immediate or urgent needs for evidence or information. In these instances, there is no time for a study to generate evidence, and decision-makers are often left rushing to find relevant evidence in which they feel confident.

d. Development partners should work with countries to explore the potential of response mechanisms designed to address information needs in a timely manner. 


\section{COUNTRY MECHANISIMS}

Though global guidelines, recommendations, and platforms are important for evidence generation and use, action at the country level is critical. Numerous development partners invest in valuable research, however these efforts are not well-coordinated and results are not consistently communicated or made available at the country level. As a result, opportunities for utilization and scale up of research evidence are often missed.

a. There is a need for coordination of research activities and organization of knowledge resources at the global and country levels. As a first priority, countries and development partners are encouraged to create a publicly accessible, searchable research repository at the national level. This repository would be managed and maintained by a relevant national organization. These organizations may require technical and/or financial assistance to strengthen their capacity to manage and maintain this repository.

b. Governments and development partners are encouraged to support national and/or sub-national research symposiums, coordinated through the Ministry of Health and/or otber relevant government bodies, to foster knowledge management and consensus building around research results and knowledge gaps.

International synthesis and guidance, following standardized and agreed upon principles and procedures, provides a widely accepted consensus on research findings. However, to best serve the needs and address the unique challenges of countries at the national and sub-national levels, international guidance must be contextualized to the local situation, and countries need tools to help make policy and program decisions appropriate for local contexts.

c. To implement evidence-based change, countries require consultative processes, resources, and capabilities for generating, synthesizing, and using locally appropriate evidence. Countries also need to be supported in adapting global guidelines for local use.

d. Policy makers and program managers are encouraged to build local capacity for and use underutilized decision-making tools, such as Root Cause Analysis and Bottleneck. Analysis, to better identify underlying causes of program constraints and bottlenecks.

Leaders must then garner support for evidence-based policy and program change.

e. Countries are encouraged to build capacity at the national and sub-national levels to use evidence-based strategies/mechanisms to garner support for policy and program change. Such strategies could include, but are not limited to, developing leadership within Ministries to advocate for change, identifying and supporting in-country champions, broadening stakeholder engagement, capacity building of policy makers and other key stakeholders for advocacy, and study tours.

\section{IMPLEMENTATION RESEARCH AND DELIVERY SCIENCE (IRDS)}

In order to meet national and international development goals, countries must move from pilot or demonstration projects that generate evidence of improved health service delivery and system improvements to nationwide implementation and institutionalization of high impact practices.

a. To be most effective, scale-up of interventions with demonstrated effectiveness through pilot projects should include processes for continual learning and adaptation as scale-up proceeds, sometimes referred to as Implementation Research and Delivery Science (IRDS). 
We recognize and applaud IRDS as a platform that brings together key development partners in an effort to introduce mechanisms to embed implementation research into policy making, program management, and monitoring and evaluation processes.

b. To operationalize this effort, governments should consider embedding IRDS in national plans and policies. Countries are encouraged to start with a review of the Cape Town Statement on IRDS. ${ }^{4}$

\section{COMMUNICATING AND PACKAGING EVIDENCE}

It is important that there is a plan to encourage the use of evidence that is generated. Packaging and communication are key elements of evidence use, so that the intended audiences receive the evidence in a clear and compelling way that will bring it into the multi-dimensional decision-making process and lead to evidence-based change.

Access to evidence is a basic, yet not always simple, element of utilization. However there is a trend, particularly among the donor community and multi-lateral organizations, to ensure open access to journal articles - at a minimum for developing country audiences, who otherwise might not have the resources to access these journals.

a. Recognizing the trend towards more open access, we encourage more journals to provide open access mechanisms and more researchers to publish in open access journals. To aid in operationalization of intervention research, we also encourage researchers and journals to include supplemental materials on the description of the intervention, beyond what space limitations make it possible to include in the article.

b. WHO and development partners should raise awareness of the availability of free joumal access through the HINARI website (who.int/HINARI) to bealth institutions in developing countries.

Additionally, those using evidence to influence the decision-making process are not a homogenous group. They have diverse opinions, preferences for receiving messages about new evidence, and formats in which they prefer to have evidence delivered.

c. To increase research utilization, researchers/research teams should segment audiences and settings by use of different messaging, tools, platforms, and packaging (e.g. multimedia, Twitter, listserv emails, HIP map).

Finally, the responsibility for research utilization should not rest solely on the researcher. Research utilization should begin at the stage of question identification, involving those with a variety of expertise, including those who can help develop and plan for evidence use and those local stakeholders who can influence its use.

d. Research proposals should include research utilization plans, and research teams should include members with a variety of skills who will help to translate the findings into action throughout the research process and not only at the end.

e. Country programs will benefit from greater utilization of evidence and data for decision making. Therefore, policy makers and other local stakebolders should seek, ways to incorporate research utilization into decision-making processes.

\footnotetext{
${ }^{4}$ http://healthsystemsglobal.org/upload/hsg_media/statement_IRDS.pdf?view-version=1.0
} 


\section{Appendix 1 | Meeting Agenda}

\section{TUESDAY FEBRUARY 9TH}

8:00 am 9:00 am

\section{BREAKFAST}

$\begin{array}{ll}\text { 9:15 am - } & \text { Welcome, participant introductions, } \\ \text { 9:30 am } & \text { overview of the meeting, logistics }\end{array}$ 0 am 10:15 am

10:15 am 11:15 am

\section{Objective 1}

Rationale and objectives for this consultation:

- Overview of previous consultations

- Contribution of this meeting to standards of evidence and rationale and expectations for this meeting

- Expected product outcomes

\section{Facilitated discussion among} country decision-makers using questions from the pre-meeting survey

\section{Objective 2}

The world of policy and program from the decision-maker perspective: what is the role for research-based evidence, among other factors?

- Group-wide understanding of decision-making processes in diverse situations

- Examples of how and when research-based evidence is and is not used

- Key constraints in using evidence
- Link this meeting to previous meetings to clarify rationale for this consultation

- Brief overview of recommendations from previous meetings

- Define products of meeting (audience, what will they look like?)

Role of research-based evidence in making decisions:

- What decisions are decision-makers faced with for which evidence could be helpful?

- How often are you faced with these decisions?

- What time frame do you have to make these decisions? (a week, month, etc.)

- Are there other constraints/parameters that influence decisions?

- How do decision-makers use evidence? (inform decisions, justify decisions, inform implementation)

\section{MODERATORS}

Karen Hardee, Evidence

Project/Population Council

Harriet Birungi, STEP-

UP/Population Council

\section{MODERATORS}

Ian Askew, WHO

Shawn Malarcher, USAID

\section{MODERATORS}

Patrick Aboagye, Ghana

Health Service 


\begin{tabular}{|l|l|l|}
\hline THME & \multicolumn{1}{|c|}{$\begin{array}{l}\text { SESSION/OBJECTIVES } \\
\text { DISCUSSION QUESTIONS/ } \\
\text { KEY POINTS }\end{array}$} & $\begin{array}{c}\text { SESSION MODERATORS/ } \\
\text { DISCUSSANTS }\end{array}$ \\
\hline $\begin{array}{l}\text { - What can producers of evidence } \\
\text { do to make research more } \\
\text { accessible/usable for decision- } \\
\text { makers? }\end{array}$ & \\
\hline
\end{tabular}

11:15 am 11:30 am

BREAK

\section{Continuation of discussion}

11:30 am12:45 pm
The world of policy and program decision-making; what is the role for research-based evidence, among other factors?
- Where do decision-makers go for input/advice? Why these sources?

- What are the key constraints to accessing and using research-based evidence? Which of these can be addressed by producers of evidence?

\section{MODERATORS}

Patrick Aboagye, Ghana Health Service
$12: 45 \mathrm{pm}-$ 2:15 pm

\section{2:15 pm - 3:45 pm}

\section{LUNCH}

Key issues related to standards of evidence. Short presentations and facilitated discussions on four issues.

Issue 1: Standards and types of evidence for demonstrating effectiveness of 'clinical,' 'public health,' and multisectoral interventions

Issue 2: Using Implementation Research to inform scale up and improve program efficiency

Issue 3: Summarizing bodies of evidence: what's behind the existing guideline acronyms?
- Articulate the differences between standards and types of evidence needed for 'clinical' and 'public health' RH/FP interventions and quality of evidence

- How is Implementation Research different than impact studies? What is the value added?

- Using different methods can yield different answers (impact assessments as well as systematic reviews)

\section{MODERATORS}

Issue 1: Karen Hardee, Evidence Project/ Population Council

Issue 2: Nhan Tran, AHSPR

Issue 3: Özge Tunçalp, WHO

\section{3:45 pm - 4:00 pm \\ BREAK}




\begin{tabular}{|c|c|c|c|}
\hline TIME & SESSION/OBJECTIVES & $\begin{array}{l}\text { DISCUSSION QUESTIONS/ } \\
\text { KEY POINTS }\end{array}$ & $\begin{array}{c}\text { SESSION MODERATORS/ } \\
\text { DISCUSSANTS }\end{array}$ \\
\hline $\begin{array}{l}\text { 4:00 pm - } \\
\text { 4:45 pm }\end{array}$ & $\begin{array}{l}\text { Issue 4: What is the role of politics } \\
\text { and expert opinion in assessing } \\
\text { standards of evidence? }\end{array}$ & & $\begin{array}{l}\text { MODERATOR } \\
\text { Issue 4: Josephine Kibaru- } \\
\text { Mbae, NCPD, Kenya }\end{array}$ \\
\hline $\begin{array}{l}\text { 4:45 pm - } \\
5: 15 \mathrm{pm}\end{array}$ & $\begin{array}{l}\text { Other issues in research evidence: } \\
\text { cost data, quality of evidence, } \\
\text { measuring sustainability }\end{array}$ & $\begin{array}{l}\text { Discussion of other issues that } \\
\text { arise related to evidence, } \\
\text { including questions about } \\
\text { evidence from participants }\end{array}$ & $\begin{array}{l}\text { MODERATOR } \\
\text { Kazuyo Machiyama, } \\
\text { LSTHM }\end{array}$ \\
\hline $\begin{array}{l}\text { 7:00 pm - } \\
8: 30 \mathrm{pm}\end{array}$ & DINNER & & \\
\hline
\end{tabular}

\section{WEDNESDAY FEBRUARY 10 ${ }^{\text {TH }}$}

8:00 am 9:00 am

BREAKFAST

9:15 am 9:25 am 9:45 am

Finalize draft recommendations from Day 1
9:25 am from Day 1
Recap of key points and highlights

MODERATOR

Tapash Das, DGFP, Bangladesh

Review and reach agreement on wording of the draft recommendation statements for objectives \#1 and \#2

What mechanisms does your ministry currently have in place to:

- Set and manage a research agenda

\section{Objective 3}

9:45 am 10:45 am

Moderated discussion with decisionmakers

\section{MODERATOR}

lan Askew, WHO
- Commission or otherwise fund research studies

- Coordinate and receive evidence from national universities / research organizations

\section{MODERATOR}

Susan Elden, DFID

DISCUSSANTS

Country decision-makers

To what extent do these mechanisms include opportunities for the different types of research discussed on day 1 ? 
DISCUSSION QUESTIONS/ KEY POINTS

How could these mechanisms be improved to generate the quality of evidence needed?
10:45 am 11:00 am

\section{BREAK}

Moderated discussion with donors

11:00 am - and researchers
You've heard from the country decision-makers.

- What have your experiences been as donors, including both successes and challenges, in supporting country-led research?

- From the discussion we've had, can you think of ways that donors and the research programs they fund could better support countries to improve their mechanisms for generating and synthesizing research, and for using evidence to inform nationallyappropriate programming?

\section{MODERATORS}

Koku Awoonor-Williams, Ghana Health Service

\section{DISCUSSANTS}

Representatives from USAID, DFID, WHO, UNFPA, the Evidence Project, StepUp Project

\section{Objective 4}

Effective packaging and communication of evidence (Group discussion)

$12: 00 \mathrm{pm}-$ 12:45 pm
Look at examples of evidence packaging and discuss how these formats could be made more useful for policy makers.
- What do you like about each format? What would you change and how?

- Does it include the information you need?

- Is it written in a way that is easy to understand and use?

- Where do you go to get information?

\section{MODERATORS}

Shawn Malarcher, USAID

\section{DISCUSSANTS}

MD Younus Mian, MOHFW, Bangladesh

(journal article)

Placid Mihayo, $\mathrm{MOH}$, Uganda

(FP HIPs)

Chito Nelson, NPHCDA, Nigeria (WHO Task Shifting guidance)

\section{2:45 pm -} 1:00 pm 


\begin{tabular}{|c|c|c|c|}
\hline TIME & SESSION/OBJECTIVES & $\begin{array}{l}\text { DISCUSSION QUESTIONS/ } \\
\text { KEY POINTS }\end{array}$ & $\begin{array}{l}\text { SESSION MODERATORS/ } \\
\text { DISCUSSANTS }\end{array}$ \\
\hline $\begin{array}{l}\text { 1:00 pm - } \\
2: 15 \text { pm }\end{array}$ & LUNCH & & \\
\hline $\begin{array}{l}2: 15 \mathrm{pm} \mathrm{-} \\
3: 45 \mathrm{pm}\end{array}$ & $\begin{array}{l}\text { Continue discussion on effective } \\
\text { packaging and communication of } \\
\text { evidence }\end{array}$ & & $\begin{array}{l}\text { MODERATOR } \\
\text { Shawn Malarcher, USAID }\end{array}$ \\
\hline $\begin{array}{l}\text { 3:45 pm - } \\
\text { 4:00 pm }\end{array}$ & BREAK & & \\
\hline $\begin{array}{l}\text { 4:00 pm - } \\
\text { 5:00 pm }\end{array}$ & $\begin{array}{l}\text { Address Parking Lot topics from } \\
\text { prior two days }\end{array}$ & & $\begin{array}{l}\text { MODERATOR } \\
\text { Robin Keeley, Evidence } \\
\text { Project/PATH }\end{array}$ \\
\hline $\begin{array}{l}\text { 7:00 pm - } \\
\text { 8:30 pm }\end{array}$ & DINNER & & \\
\hline
\end{tabular}

\section{THURSDAY FEBRUARY 12 $^{\text {TH }}$}

8:00 am 9:00 am

9:15 am 9:25 am Recap of key points and highlights from Day 2

\section{BREAKFAST}

\section{9:25 am -} 9:45 am

Finalize draft recommendations from Day 2
Draft the agreed-upon recommendations as short, action-oriented bullet points that can be framed as a consensus statement

\section{MODERATOR}

Naeem Zafar, Ministry of Planning, Development \& Reform, Pakistan

\section{MODERATOR}

Harriet Birungi, STEPUP/Population Council

\section{Objective 5}

Preparing a consensus statement

9:45 am 11:00 am
Group Discussion: Reflecting on the recommendations from the Croyden meeting, discuss key points of agreement from the consultation on standards of evidence from the perspective of decision-makers, including design and implementation of research to help

\section{MODERATORS}

Karen Hardee, Evidence

Recommend processes to better align research with decision-makers' needs
Project/Population Council

Shawn Malarcher, USAID 


\begin{tabular}{|c|c|c|c|}
\hline TIME & SESSION/OBJECTIVES & $\begin{array}{l}\text { DISCUSSION QUESTIONS/ } \\
\text { KEY POINTS }\end{array}$ & $\begin{array}{l}\text { SESSION MODERATORS/ } \\
\text { DISCUSSANTS }\end{array}$ \\
\hline & $\begin{array}{l}\text { decision-makers, and the synthesis, } \\
\text { packaging and communication of } \\
\text { research results to best reach } \\
\text { decision-makers }\end{array}$ & & \\
\hline $\begin{array}{l}\text { 11:00 am - } \\
11: 15 \mathrm{am}\end{array}$ & BREAK & & \\
\hline $\begin{array}{l}11: 15 \mathrm{am}- \\
12: 45 \mathrm{pm}\end{array}$ & $\begin{array}{l}\text { Final recommendations for the } \\
\text { consensus statement. Discussion on } \\
\text { plans for preparation of consensus } \\
\text { statement and meeting report, } \\
\text { including authorship and process for } \\
\text { finalizing the report, publication and } \\
\text { dissemination. } \\
\text { Evaluation } \\
\text { Wrap-up }\end{array}$ & $\begin{array}{l}\text { The purpose of the consensus } \\
\text { statement is to inform and } \\
\text { influence the funding, design, } \\
\text { implementation and } \\
\text { communication of research on } \\
\text { reproductive and maternal } \\
\text { health policies and programs in } \\
\text { developing countries. }\end{array}$ & $\begin{array}{l}\text { MODERATORS } \\
\text { Karen Hardee, Evidence } \\
\text { Project/Population Council } \\
\text { Harriet Birungi, STEP- } \\
\text { UP/Population Council }\end{array}$ \\
\hline
\end{tabular}




\section{Appendix 2 | List of Participants}

\begin{tabular}{|c|c|c|c|}
\hline NAME & COUNTRY & TITLE & ORGANIZATON \\
\hline Mr. MD Younus Mian & Bangladesh & $\begin{array}{l}\text { Deputy Chief (Planning } \\
\text { Wing) }\end{array}$ & $\begin{array}{l}\text { Ministry of Health and } \\
\text { Family Welfare }\end{array}$ \\
\hline Dr. Tapash Ranjan Das & Bangladesh & Deputy Director, $\mathrm{MCH}$ & $\begin{array}{l}\text { Directorate General of } \\
\text { Family Planning }\end{array}$ \\
\hline Dr. Patrick Aboagye & Ghana & $\begin{array}{l}\text { Director of Family Health } \\
\text { Division }\end{array}$ & Ghana Health Service \\
\hline $\begin{array}{l}\text { Dr. Koku Awoonor- } \\
\text { Williams }\end{array}$ & Ghana & $\begin{array}{l}\text { Director of Policy Planning } \\
\text { Monitoring \& Evaluation }\end{array}$ & Ghana Health Service \\
\hline $\begin{array}{l}\text { Dr. Josephine Kibaru- } \\
\text { Mbae }\end{array}$ & Kenya & Director General & $\begin{array}{l}\text { National Council for } \\
\text { Population and } \\
\text { Development }\end{array}$ \\
\hline Mrs. Chito Nelson & Nigeria & Deputy Director (HSS) & $\begin{array}{l}\text { National Primary Health } \\
\text { Care Development } \\
\text { Agency }\end{array}$ \\
\hline Dr. Naeem-uz-Zafar & Pakistan & $\begin{array}{l}\text { Member, Social Sectors \& } \\
\text { Devolution }\end{array}$ & $\begin{array}{l}\text { Ministry of Planning, } \\
\text { Development \& Reform }\end{array}$ \\
\hline Dr. Placid Mihayo & Uganda & Assistant Commissioner RH & Ministry of Health \\
\hline Dr. Ian Askew & Switzerland & $\begin{array}{l}\text { Director, Department of } \\
\text { Reproductive Health and } \\
\text { Research }\end{array}$ & WHO \\
\hline Dr. Özge Tuncalp & Switzerland & $\begin{array}{l}\text { Department of Reproductive } \\
\text { Health and Research }\end{array}$ & WHO \\
\hline Dr. Nhan Tran & Switzerland & $\begin{array}{l}\text { Alliance for Health Policy } \\
\text { and Systems Research }\end{array}$ & WHO \\
\hline Ms. Shawn Malarcher & USA & $\begin{array}{l}\text { Senior Best Practices } \\
\text { Utilization Advisor }\end{array}$ & USAID \\
\hline Mr. Neal Brandes & USA & Research Advisor & USAID \\
\hline Mrs. Susan Elden & $\begin{array}{l}\text { United } \\
\text { Kingdom }\end{array}$ & $\begin{array}{l}\text { Health Adviser, Human } \\
\text { Development Research } \\
\text { Team, Research and } \\
\text { Evidence Division }\end{array}$ & DfID \\
\hline Dr. Karen Hardee & USA & $\begin{array}{l}\text { Senior Associate and Project } \\
\text { Director }\end{array}$ & $\begin{array}{l}\text { The Evidence Project, } \\
\text { Population Council }\end{array}$ \\
\hline Ms. Robin Keeley & USA & $\begin{array}{l}\text { Research Utilization } \\
\text { Specialist }\end{array}$ & $\begin{array}{l}\text { The Evidence Project, } \\
\text { PATH }\end{array}$ \\
\hline Dr. Harriet Birungi & Kenya & $\begin{array}{l}\text { Kenya Population Council } \\
\text { Country Director and Project } \\
\text { Director }\end{array}$ & $\begin{array}{l}\text { STEP UP Project, } \\
\text { Population Council }\end{array}$ \\
\hline Dr. Kazuyo Machiyama & $\begin{array}{l}\text { United } \\
\text { Kingdom }\end{array}$ & Faculty & $\begin{array}{l}\text { London School of } \\
\text { Hygiene \& Tropical } \\
\text { Medicine }\end{array}$ \\
\hline Dr. Eugene Kongnyuy & DRC & $\begin{array}{l}\text { H4+ Coordinator and Chief } \\
\text { Technical Advisor }\end{array}$ & UNFPA \\
\hline
\end{tabular}




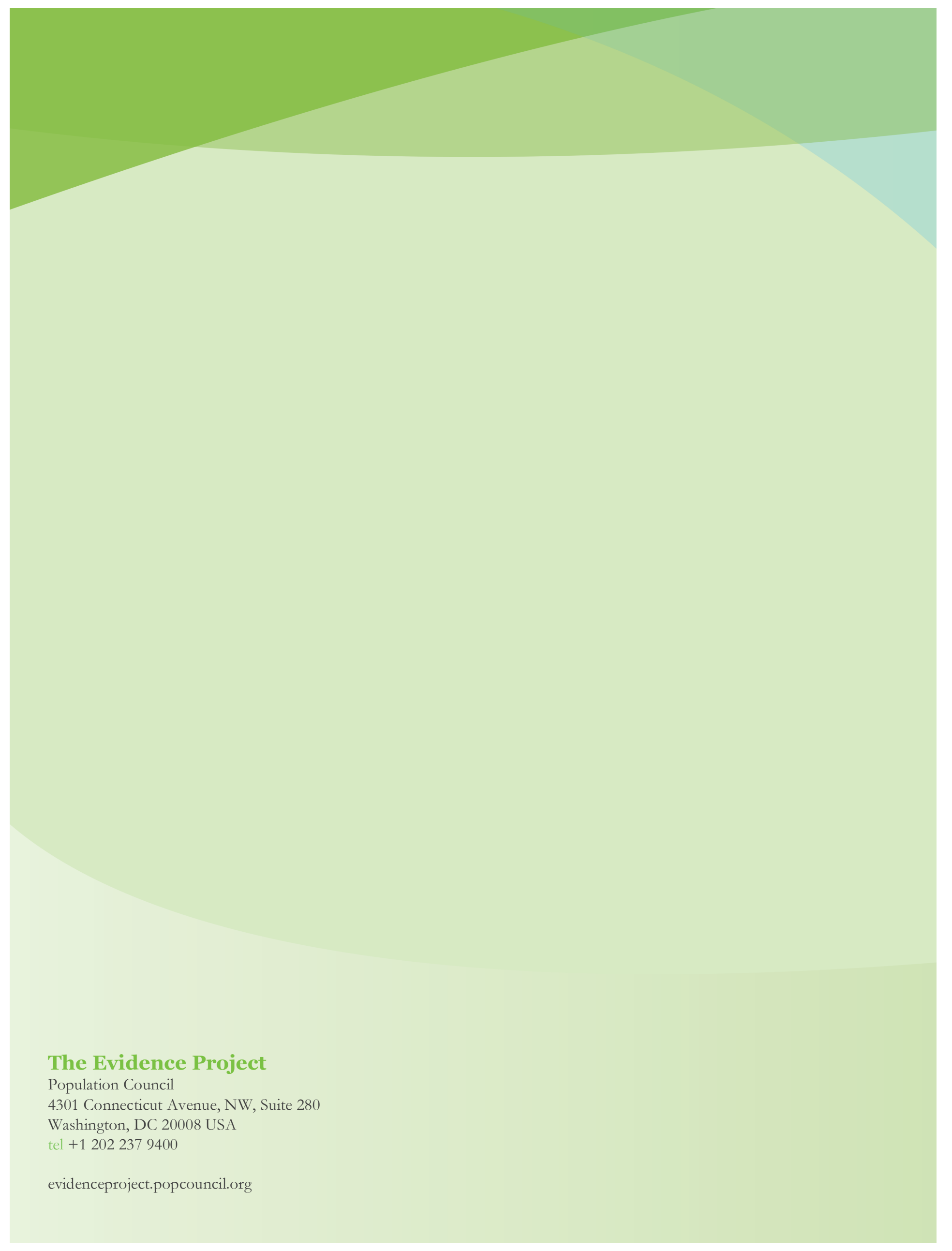

